\title{
LELANG EKSEKUSI HAK TANGGUNGAN PADA PERBANKAN SYARIAH MENURUT HUKUM POSITIF DAN FIQH MUAMALAH
}

\author{
Husni Kamal \\ Email: husnikamal@iainlhokseumawe.ac.id
}

\begin{abstract}
The purpose of this research is to find out the execution auction conducted by sharia banks at KPKNL in Banda Aceh and the execution auctions according to a review of positive and Fiqh law. These types of research using descriptive analysis are describing and analyzing the auction-related execution. In conclusion, according to the positive law of the execution auction conducted by sharia banks in KPKNL already in accordance with the prevailing requirements and regulations, while according to the Fiqh rulings in the implementation there is still the occurrence of fraud committed by the auction mafia during the execution process of KPKNL that will affect the creditor on the sale of objects of liability.
\end{abstract}

Keywords: Sharia Bank, Auction execution, sharia economic

\begin{abstract}
ABSTRAK
Tujuan penelitian ini untuk mengetahui pelelangan eksekusi yang dilakukan oleh bank syariah pada KPKNL di Banda Aceh dan lelang eksekusi menurut tinjauan hukum positif dan fiqh muamalah. Adapaun jenis penelitian ini menggunakan deskriptif analisis yaitu menggambarkan dan menganalisa terkait lelang eksekusi. Kesimpulannya menurut hukum positif lelang eksekusi yang dilakukan yang dilakukan oleh bank syariah pada KPKNL sudah sesuai dengan persyaratan dan peraturan yang berlaku, sedangkan menurut fiqh muamalah pada pelaksanaanya masih ada terjadinya kecurangan yang dilakukan oleh mafia lelang pada saat proses pelelangan eksekusi di KPKNL yang akan berdampak pada kreditur terhadap penjualan objek hak tanggungan.
\end{abstract}

Kata kunci: Bank Syariah, Lelang Eksekusi, Ekonomi Syariah

\section{A. PENDAHULUAN}

Lelang sebagai alternatif cara penjualan barang merupakan sistem penjulan yang cukup lama telah dikenal. Sementara itu, (Sudikno Mertokusumo, 1998) lelang di Indonesia mulai dikenal sejak tahun 1908 dengan dikeluarkannya Vendu Reglement (peraturan lelang staatsblad Tahun 1908 Nomor 189 sebagaimana yang telah diubah dengan staatsblad Tahun 1940 Nomor 56). Sesuai dengan perkembangan dalam pelaksanaan lelang maka diterbitkan keputusan menteri keuangan maupun keputusan Dirjen Piutang dan Lelang Negara.
Dalam peraturan tersebut, (Harahap, 1989) menyebutkan bahwa yang dimaksud lelang adalah pelelangan atau penjualan barang yang diadakan di muka umum dengan penawaran harga yang makin meningkat, Jika dalam proses pelelangan, peserta lelang tidak memberikan penawaran terhadap objek yang dilelang, maka jaminan yang diberikan pada saat pemenuhan prosedur lelang tersebut akan masuk ke dalam kas negara, serta peserta lelang tersebut dilarang mengikuti pelelangan di seluruh Indonesia, selama 3 bulan.

Pelelangan eksekusi merupakan penjualan umum untuk melaksanakan 
putusan pengadilan atau dokumendokumen lain, yang sesuai dengan peraturan perundang-undangan yang berlaku, dipersamakan dengan itu, dalam rangka membantu penegakan hukum, jadi khusus barang lelang sitaan putusan pengadilan negeri, disebut dengan pelelangan eksekusi. Pelaksanaan lelang eksekusi bertujuan untuk mencairkan sejumlah tagihan nasabah atas debitur yang ingkar janji (wanprestasi) di perbankan. Dalam hal ini apabila pelaksanaan putusan telah sampai pada tahap pelaksanaan lelang, umumnya tidak dapat lagi dihentikan dengan perlawanan debitur maupun pihak ketiga. Perlawanan pihak ketiga hanya dapat diajukan berdasarkan pengakuan bahwa barang yang dilelang adalah miliknya.

Pelelangan eksekusi pada Hak tanggungan diatur di dalam UU Nomor 4 Tahun 1996 Pasal 6 Tentang hak tanggungan, yaitu:

“Apabila debitur cidera janji, pemegang Hak Tanggungan pertama mempunyai hak untuk menjual obyek Hak Tanggungan atas kekuasaan sendiri melalui pelelangan umum serta mengambil pelunasan piutangnya dari hasil penjualan tersebut".

Definisi Hak Tanggungan sesuai dengan undang-undang no.4 tanggal 9 April 1996 pasal 1 ayat 1 adalah Hak Tanggungan atas tanah beserta benda- benda yang berkaitan dengan tanah, yang selanjutnya disebut Hak Tanggungan, adalah Hak jaminan yang dibebankan pada hak atas tanah sebagaimana dimaksud dalam undang-undang nomor 5 tahun 1960 tentang peraturan dasar pokok-pokok Agraria, atau benda lain yang merupakan kesatuan dengan tanah itu, untuk pelunasan utang tertentu terhadap kreditur-kreditur lain.

Pihak-pihak yang terkait dalam pelelangan adalah sebagai berikut: pertama, nasabah, yaitu orang yang telah meminjam uang pada debitur namun tidak melaksanakan kewajibannya sesuai yang disepakati. Kedua, Debitur, yaitu pihak bank atau lembaga yang memberikan modal kepada nasabah. Ketiga, badan Urusan Piutang dan Lelang Negara (BUPLN). Keempat, pihak pembeli barang jaminan yaitu orang atau badan yang telah membeli atau menang dalam pelelangan barang jaminan. (Salim, 2004)

Dalam fiqh mu'amalah, lelang dikenal dengan istilah muzayadah. muzayadah sendiri berasal dari kata ziyadah yang artinya bertambah. Muzayadah berarti saling menambahi. Maksudnya, orangorang saling menambahi harga tawar atas suatu barang. (Imam Ash-Shan'ani, 1995)

(Ibnu Rusyd, 1992) Jual-beli secara lelang tidak termasuk praktik riba meskipun ia dinamakan bai' muzayadah dari 
kata ziyadah yang bermakna tambahan sebagaimana makna riba, namun pengertian tambahan di sini berbeda. Dalam muzayadah yang bertambah adalah penawaran harga lebih dalam akad jual beli yang dilakukan oleh penjual atau bila lelang dilakukan oleh pembeli maka yang bertambah adalah penurunan tawaran. Sedangkan dalam praktik riba tambahan haram yang dimaksud adalah tambahan yang tidak diperjanjikan dimuka dalam akad pinjam-meminjam uang atau barang ribawi lainnya.

Adapun penelitian ini bertujuan untuk mengetahui dan memberikan gambaran mengenai lelang eksekusi dalam perbankan syariah menurut hukum positif dan Fiqh Muamalah.

\section{B. KAJIAN LITERATUR}

Literatur yang menyinggung tentang permasalahan pelangan eksekusi terhadap hak tanggungan, ditulis oleh Zumrotul Malikah yang berjudul "Konsep Harga Lelang Dalam Perspektif Islam". Dalam skripsinya mengkaji tentang dua permasalahan, mengenai mekanisme penetapan harga perspektif ekonomi Islam dan pandangan ekonomi terhadap harga dalam sistem lelang. Hasil penelitian tersebut menunjukkan bahwa dalam penetapan harga dalam ekonomi Islam dengan mempertimbangkan harga yang pantas yaitu harga yang adil yang memberikan perlindungan kepada konsumen. Dan konsep harga dalam sistem lelang adalah harga ditentukan oleh juru lelang dengan melihat keadaan fisik barang tersebut dan tidak meninggalkan Nilai Limit atau lebih dikenal dengan Harga Limit Lelang. Tujuannya agar tidak adanya trik-trik kotor komplotan lelang (auction ring) dan komplotan penawar.

Kemudian tesis yang ditulis oleh Elman Simangunsong yang membahas tentang Pelaksanaan Lelang Eksekusi Atas Putusan, Proses Pelaksanaan Lelang Eksekusi Sertifikat Hak Tanggungan Berdasarkan Parate Eksekusi, dan Perlawanan Terhadap Lelang dan atau Sita Eksekusi Pengadilan, berdasarkan Pelaksanaan Lelang Eksekusi berdasarkan Parate Eksekusi di Kantor Kekayaan Negara Kantor Pelayanan Kekayaan Negara dan Lelang (KPKNL) Medan membuktikan bahwa lelang eksekusi tersebut tidak mudah dan tidak sederhana bahkan kerap tidak ada kepastian hukum, selain panjangnya prosedur yang ditempuh juga karena adanya hambatan.

Adapun perbedaan kedua penelitian tersebut dengan kajian ini yaitu terletak di fokus lelang ekseskusi dalam bank syariah serta membandingkan antara lelang dalam perspektif hukum positif dan fiqh muamalah.

\section{a. Lelang Eksekusi}


Pengertian lelang telah dirumuskan oleh beberapa pakar diantaranya, Roell (Kepala Inspeksi lelang tahun 1932) yang dikutip oleh Effendi Pranangin Angin, menyatakan bahwa lelang atau penjualan umum adalah:

"Suatu rangkaian kejadian yang terjadi antara saat dimana seseorang hendak menjual suatu barang atau lebih, baik secara pribadi maupun dengan perantaraan kuasanya memberi kesempatan kepada orang-orang yang hadir melakukan penawaran untuk membeli barang atau barang-barang yang ditawarkan sampai pada suatu saat dimana kesempatan itu lenyap". (Effendi Parangin Angin, 1994)

Pasal 1 angka 1 keputusan Menkeu No. 304/KMK 01/2002, sebagaimana diubah dengan Keputusan Menkeu No. 450/KMK 01/2002, yang berbunyi:

"Lelang adalah penjualan barang yang terbuka untuk umum baik secara langsung maupun melalui media elektronik dengan cara penawaran harga secara lisan dan/atau tertulis yang didahului dengan usaha mengumpulkan peminat".

Dari pengertian yang telah disebutkan di atas tampak bahwa lelang harus memenuhi empat unsur yaitu: Pertama Melakukan penjualan pada waktu dan tempat yang telah ditentukan, kedua terlebih dahulu mengadakan pengumuman untuk mengumpulkan peserta lelang yang berminat terhadap objek yang akan dilelang, ketiga penawaran atau pembentukan harga yang khusus, yaitu dengan cara penawaran harga secara lisan atau secara tertulis yang bersifat kompetitif dan keempat peserta yang mengajukan penawaran tertinggi akan dinyatakan sebagai pemenang atau pembeli. Pengertian eksekusi menurut M. Yahya Harahap, adalah pelaksanaan secara paksa putusan pengadilan dengan bantuan kekuatan hukum apabila pihak yang kalah (tereksekusi atau pihak tergugat) tidak mau menjalankan secara sukarela. Sudikno Mertokusumo mengatakan, pelaksanaan putusan hakim atau eksekusi pada hakikatnya tidak lain ialah realisasi dari pada kewajiban pihak yang bersangkutan untuk memenuhi prestasi yang tercantum dalam putusan tersebut. (Sudikno, 1998)

Pelelangan eksekusi merupakan lelang pelaksanaan putusan dan atau penetapan pengadilan, dokumendokumen lain yang dipersamakan dengan itu, dan/atau melaksanakan ketentuan dalam peraturan perundang-undangan. (Peraturan Menteri Keuangan, 2010)

b. Lelang Ekseskusi dalam Hukum Positif 
(Sudikno, 1998) Peraturan perundang-undangan lelang di Indonesia berlandaskan kepada Vendu Reglement (Peraturan Lelang) Ordonansi 28 Februari 1908 Staatsblad 189 Tahun 1908, yang mulai berlaku tanggal 1 April 1908 kemudian diubah dengan Staatsblad 56 Tahun 1940 juncto Staatsblad 3 Tahun 1941. Dengan demikian, Vendu Reglement dapat dikatakan sebagai landasan struktural atas keberadaan lelang di Indonesia. Selain Vendu Reglement juga dikenal Vendu Instructie (Instruksi Lelang Staatsblad 1908 Nomor 190 sebagaimana telah diubah dengan Staatsblaad 1930 Nomor 85) sebagai peraturan pelaksana.

Sedangkan Landasan operasional bagi pelaksanaan lelang yang terdapat dalam Peraturan Pelaksanaan Tentang Lelang sejak tahun 2000 sampai dengan tahun 2008 untuk memperbaiki mekanisme dan pelaksanaan lelang menjadi lebih baik dan jelas, tercatat dalam beberapa Surat Keputusan yang berada pada lingkup peraturan lelang antara lain sebagai berikut:

1. Keputusan Menkeu Nomor: 507/KMK.Ol/2000

Dalam keputusan menteri keuangan nomor 507 ini membahas tentang pelaksanaan lelang yang berkaitan dengan peserta lelang menyetor uang jaminan penawaran lelang yang besarnya ditentukan oleh penjual, kecuali ditentukan lain, kemudian nilai limit ditentukan oleh Penjual dan diserahkan kepada Pejabat Lelang selambatlambatnya pada saat akan dimulainya pelaksanaan lelang. kecuali ditentukan lain oleh peraturan perundang-undangan yang berlaku.

2. Peraturan Menkeu Nomor 40/PMK.07/2006.

Peraturan ini terkait tentang Petunjuk Pelaksanaan Lelang yang membahas tentang pelaksanaan lelang harus dilakukan dihadapan Pejabat Lelang kecuali ditentukan lain oleh peraturan perundang-undangan. Pelelangan yang telah dilaksanakan sesuai dengan ketentuan yang berlaku tidak dapat dibatalkan. Serta membahas tentang tata cara permohonan lelang.

3. Peraturan Menkeu Nomor 150/PMK.06/2007

Dalam Peratuan Menteri Keuangan ini membahas tentang petunjuk pelaksanaan lelang, dimana hal ini terkai dengan tempat pelaksanaan lelang harus di laksanakan wilayah kerja KPKNL atau di wilayah jabatan Pejabat Lelang Kelas II tempat barang berada atau temapt pelaksanaan lelang dapat di tentkan lokasinya oleh pejabat KPKNL

4. Peraturan Menkeu Nomor 61/PMK.06/2008, 
Peraturan Menteri Keuangan Nomor 61 ini, juga membahas tentang petunjuk pelaksanaan lelang yang diperbaharui pada tanggal tanggal 25 April 2008. Didalamnya mencakup tentang efisiensi dan efektifitas pengumuman lelang, khususnya untuk lelang non eksekusi.

\section{c. Lelang Eksekusi dalam Fiqh Muamalah}

Pelelangan dalam Fiqh mu'amalah disebut juga dengan istilah Muzayadah yang mana pelaksanaannya hampir sama dengan pelelangan yang dilakukan di KPKNL. Lelang termasuk salah satu bentuk jual beli, akan tetapi ada perbedaan secara umum. Jual beli ada hak memilih, sedangkan lelang tidak ada hak memilih, seta pelaksanaannya dilakukan khusus di muka umum. (Aiyub Ahmad, 2004).

\section{Lelang (Muzayadah), arti secara}

bahasa (lughah-etimologi) adalah:

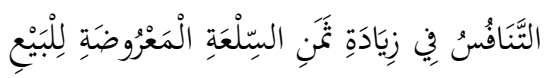

"Berlomba-lomba dalam menambah harga barang dagangan yang dipamerkan untuk dijual".

Sedangkan secara istilah pengertian Muzayyadah adalah sebagai beikut:

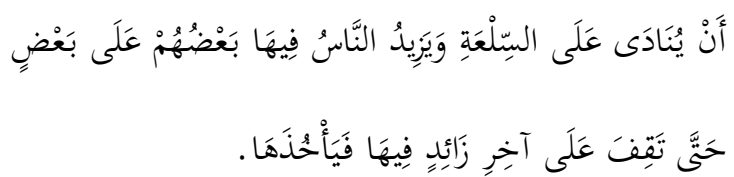

Jual beli model lelang (muzayadah) dalam hukum Islam adalah boleh mubah. Ibnu Abdi Dar berkata, "Sesungguhnya tidak haram menjual barang kepada orang dengan adanya penambahan harga (lelang), dengan kesepakatan di antara semua pihak". Adapun menurut Ibnu 'Abdil Barri adanya kesepakatan ulama tentang bolehnya jual-beli secara lelang bahkan telah menjadi kebiasaan yang berlaku di pasar umat Islam pada masa lalu. (Imam Ash-Shan'ani, 1995)

Menurut Muhammad dan Abu Yusuf (ahli ekonomi Islam klasik) memperbolehkan menjual aset kekayaan (obyek hak tanggungan) pihak kreditur jika qadhi (hakim) telah mengeluarkan putusan terhadapnya dan tidak ditemukan alasan pembenar untuk menunda penjualan tersebut. Penjualan tersebut dalam semua kasus harus dilakukan atas sepengetahuan qadhi serta dihadiri oleh para pihak di pasar barang yang akan di jual, penjualan itu juga bisa dilakukan dengan cara lelang atau mendapatkan harga setinggi mungkin sesuai dengan harga pasar pada saat lelang berlangsung. (Wahbah az-zuhaili, 2011)

\section{d. Faktor Terjadinya Lelang Eksekusi di Bank Syariah}

Pada dasarnya tidak ada nasabah yang menginginkan barang jaminan atau benda lainnya dilelang oleh kantor 
pelayanan kekayaan dan lelang negara (KPKNL). Ada beberapa faktor pemicu terjadinya wanprestasi yang dilakukan oleh pihak kreditur sehingga terjadinya pelelangan eksekusi terhadap obyek hak tanggungan adalah sebagai berikut: (Salim, 2005)

1. Kondisi ekonomi nasabah

Pada umumnya yang meminjam uang pada lembaga perbankan adalah nasabah menengah ke bawah, sehingga didalam pengembangan usahanya selalu tergantung pada harga pasar yang berlaku. Di dalam prinsip ekonomi, semakin banyak barang yang di jual di pasar, maka semakin rendah harga barang tersebut. Ketika hal ini terjadi, maka dengan terpaksa mereka menjual barang dagangannya dengan harga yang rendah, pada akhirnya mereka tidak mampu membayar hutang kredit pada lembaga perbankan, sedangkan uang yang diterima cukup untuk membayar biaya pengelolaan usahanya saja.

2. Kemauan debitur untuk membayar hutangnya sangat lemah

Rendahnya kemauan debitur untuk membayar hutangnya disebabkan oleh obyek jaminan yang digunakan olehnya adalah tanah milik orang lain, hal ini disebabkan oleh pemilik tanah memerlukan uang sehingga ia menyuruh orang lain untuk memperoleh kredit tersebut dengan menggunakan obyek jaminan miliknya.

3. Usaha kreditur Bangkrut

Bangkrutnya usaha nasabah ini disebabkan oleh bisnis yang dikembangkannya sangat banyak dan adanya pengaruh krisis ekonomi, banyaknya usaha yang dikembangkan kreditur ini membuat biaya yang dikeluarkan untuk mengembangkan usahanya tersebut menjadi bertambah.

4. Kredit yang digunakan kreditur disalahgunakan

Permohonan pengajuan dana kredit uang diusulkan pada Bank/ lembaga keuangan kredituir telah menentukan tujuan kredit yang diajukannya, namun mereka tidak menggunakan uang tersebut sebagaimana mestinya. Kreditur menggunakan kredit yang diterimanya untuk kepentingan yang bersifat konsumtif.

\section{METODE PENELITIAN}

Adapun jenis penelitian ini menggunakan deskriktif analitis. Deskriktif dalam arti bahwa dalam penelitian ini penulis bermaksud untuk menggambarkan dan melaporkan secara rinci, sistematis dan menyeluruh mengenai segala sesuatu yang berkaitan dengan lelang khususnya lelang eksekusi yang dilakukan oleh Bank Syariah melalui KPKNL. Sedangkan analitis adalah 
mengandung makna mengelompokkan, menghubungkan data-data yang diperoleh baik dari segi teori maupun dari segi praktik yang kemudian akan dianalisis guna memperoleh gambaran yang utuh dan menyeluruh tentang masalah-masalah yang diteliti. Jadi penelitian deskriptif analitis adalah suatu metode penelitian untuk memperoleh gambaran mengenai keadaan, dengan cara memaparkan data yang diperoleh yang kemudian dianalisis dan menyusun kesimpulan.

Adapun sumber data yang dipergunakan dalam penelitian ini yang pertama data primer yang didapatkan melalui wawancara langsung di KPKNL Banda Aceh. Yang kedua data sekunder yang didapatkan melalui peraturan perundang-undangan, buku-buku, literatur, jurnal dan dokumen yang berkaitan dengan pokok masalah.

\section{HASIL DAN PEMBAHASAN}

1. Tinjauan Hukum Positif terhadap Mekanisme Lelang Eksekusi pada KPKNL Banda Aceh.

Seiring terjadinya suatu perjanjian yang telah disepakati bersama tanpa dipenuhi prestasinya sebagaimana mestinya oleh salah satu pihak atau terjadinya wanprestasi (ingkar janji). Pada umumnya yang melakukan wanprestasi atau ingkar janji adalah debitur, dengan demikian pihak kreditur berhak meminta ganti rugi terhadap biaya rugi yang dideritanya. Pihak debitur umumnya sudah memberikan peringatan kepada pihak kreditur untuk melunasi kewajibannya namun kreditur tetap lalai sehingga diambil langkah hukum lebih lanjut, maka salah satu langkah hukum yang dipilih oleh debitur agar piutangnya dapat dilunasi oleh kreditur adalah dengan melakukan pelelangan eksekusi terhadap obyek hak tanggungan di KPKNL (Kantor Pelayanan Kekayaan Negara dan Lelang).

Dari uraian diatas maka obyek hak tanggungan itu berhak dijual oleh pemegang hak tanggungan tanpa persejutuan dari pemilik hak tanggungan dan tidak dapat menyatakan keberatan terhadap peenjualan yang dilakukan oleh pemegang hak tanggungan. Pelaksanaan pelelangan terhadap hak tanggungan ini ditentukan oleh perundang-undangan yang bertujuan untuk pelunasan piutang pemegang hak tanggungan dengan hak mendahului kreditur-kreditur lainnya. Eksekusi pelelangan dilakukan agar penjualan itu dapat dilakukan secara jujur dan diperoleh harga yang paling tinggi untuk obyek hak tanggungan yang dilelang, sehingga dapat menutupi hutang debitur pada kreditur. (M. Bahsan, 2007)

Dari prosedur pelelangan yang telah dijelaskan sebelumnya, pelaksanaan pelelangan eksekusi pada obyek hak 
tanggungan telah memenuhi SOP (standard operating procedure). Dengan demikian setiap pelaksanaan pelelangan yang telah dijalankan pada badan lelang Kantor Pelayanan Kekayaan Negara dan Lelang (KPKNL) sudah sejalan dengan ketetapan dan aturan dalam perundang-undangan yang berlaku.

2. Tinjauan Fiqh Mu'amalah terhadap Mekanisme Lelang Eksekusi pada KPKNL Banda Aceh

Sesuai dengan mekanisme dan penerapannya, pelelangan dapat dikatagorikan sebagai salah satu bentuk jual beli, akan tetapi ada perbedaan dengan jual beli secara umum. Dalam jual beli terdapat hak khiyar, sedangkan dalam pelelangan tidak terdapat hak khiyar. Ini bertujuan agar barang yang dilelang pada saat itu juga terjual sesuai dengan penawaran yang ditawarkan oleh pihak pembeli.

Dalam kitab Subulussalam, Ibnu Abdil Barr menyebutkan untuk mencegah adanya penyimpangan syariat dan pelanggaran hak, norma dan etika dalam praktik lelang maupun praktek jual beli yang lain, syariat Islam memberikan panduan dan kriteria umum sebagai garis petunjuk diantaranya:

1. Transaksi dilakukan oleh pihak yang cakap hukum atas dasar saling sukarela('an taradhin).
2. Objek lelang atau barang yang diperjualbelikan harus halal dan bermanfaat.

3. Kepemilikan penuh pada barang atau jasa yang dijual.

4. Kejelasan dan transparansi barang atau jasa yang dilelang atau yang diperjual belikan tanpa adanya manipulasi seperti window dressing atau lainnya.

5. Kesanggupan penyerahan barang dari penjual kepada Pembeli.

6. Kejelasan dan kepastian harga yang disepakati tanpa berpotensi menimbulkan perselisihan.

7. Tidak menggunakan cara yang menjurus kepada kolusi dan suap untuk memenangkan lelang dan tawar-menawar harga.

Segala bentuk rekayasa curang untuk mengeruk keuntungan tidak sah dalam praktik lelang dikategorikan para ulama dalam praktik Najasy (curang dalam tender dan lelang) yang diharamkan Nabi SAW. Hal tersebut dapat juga dimasukkan dalam kategori Risywah (sogok) bila penjual atau pembeli menggunakan uang, fasilitas ataupun service untuk memenangkan lelang yang sebenarnya tidak memenuhi kriteria yang dikehendaki mitra bisnisnya.

Konsep harga lelang yang digunakan adalah penentuan harga oleh penjual dengan menggunakan harga limit 
sesuai dengan Islam walaupun harga yang ditentukan tidak sesuai dengan mekanisme pasar pada umumnya. Akan tetapi, penentuan harga yang dilakukan dalam pelelangan menuju pada konsep keadilan dengan tujuan untuk melindungi penjual maupun pembeli supaya tidak menimbulkan eksploitasi atau penindasan sehingga merugikan salah satu pihak dan menguntungkan pihak yang lain. Disamping itu untuk mencegah adanya kecurangan berupa komplotan lelang (auction ring) dan komplotan penawar (bidder's ring) yaitu sekelompok pembeli dalam lelang yang melalukan kerja sama untuk menawar dengan harga yang sangat rendah, jika berhasil kemudian dilelang sendiri diantara mereka. Penawaran curang seperti itu disebut penawaran cincai (collusive bidding). Pembatasan harga terendah yang dilakukan untuk mencegah permainan curang antara penjual lelang (kuasa penjual) dan pembeli yang akan merugikan pemilik barang. (Guntur Priadi, 2019)

Terkait dengan kecurangan yang dilakukan oleh peserta lelang dalam penentuan pemenang lelang terhadap barang yang sedang dilelang, hal ini tidak berpengaruh terhadap jalannya/ proses berlangsungnya pelelangan eksekusi, karena pada dasarnya hal ini tidak mengganggu prosedur yang telah ditetapkan oleh KPKNL (Kantor
Pelayanan Kekayaan Negara dan Lelang). Walaupun petugas pelelangan telah mengetahui adanya kejanggalankejanggalan yang dilakukan oleh peserta lelang dalam pelelangan yang sedang berlangsung, petugas lelang tidak bisa melakukan tindakan pencegahan terhadap mafia lelang tersebut.

Dari paparan diatas diketahui bahwa, kecurangan yang dilakukan oleh mafia lelang (bidder's ring) bukanlah suatu hambatan dalam mekanisme pelelangan, padahal dalam hal ini, sangat jelas merugikan pihak yang memiliki obyek hak tanggungan yang menjadi obyek lelang, alih-alih pihak debitur mendapat harga jual jauh lebih tinggi dari harga limit, sehingga dapat melunasi hutangnya kepada kreditur dan mendapat keuntungan dari pelelangan tersebut yang seharusnya pihak debitur hanya bisa melunasi hutangnya kepada kreditur, tanpa ada keuntungan yang didapat dari hasil penjualan obyek lelang tersebut.

\section{E. KESIMPULAN}

Berdasarkan hasil kajian dan analisis penulis terhadap hasil penelitian yang telah diuraikan sebelumnya, maka dapat diambil kesimpulan sebagai berikut:

1. Prosedur pelelangan eksekusi di Banda Aceh pada KPKNL pelaksanaan pelelangan telah memenuhi SOP (standard operating 
procedure) dengan demikian tercapailah persyaratan dan fungsi pelelangan yang sesuai dengan peraturan perundang-undangan yang berlaku, terdapat 4 (empat) tahapan pokok dalam pelaksanaan lelang Obyek hak tanggungan, yaitu: pertama persiapan lelang, kedua pelaksanaan lelang, ketiga risalah lelang, dan keempat, pembukuan dan pelaporan lelang.

2. Tinjauan Fiqh Muamalah terhadap mekanisme lelang eksekusi secara keseluruhan lelang eksekusi yang dilakukan oleh bank syariah pada KPKNL tidak bertentangan dengan norma-norma Islam, dalam artian setiap pelaksanaan yang dilakukan terhadap pelelangan dan prosedurnya tidak bertentangan dengan Fiqh Mu'amalah, hanya saja pada praktek pelaksanaannya obyek hak tanggungan terdapat mafia lelang yang melakukan kecurangan yang mengakibatkan kerugian bagi pemilik hak tanggungan.

\section{DAFTAR PUSTAKA}

Aiyub Ahmad. (2004). Fikih Lelang Perspektif Hukum Islam Dan Hukum Positif. Jakarta: Kiswah.
Effendi Parangin Angin. (1994). Peraturan Lelang. Jakarta: Esa Study Club.

Guntur Priadi. (2019). seksi pelayanan lelang KPKNL di Banda Aceh

Ibnu Rusyd. (1992). Bidayatul Mujtahid. Beirut: DarEl Al Kutub Juz. II.

Imam Ash-Shan'ani (1995). Subulus Salam. Juz. III, Beirut, Lebanon: Darul Kutub Al-Ilmiyah.

Keputusan Menteri Keuangan Nomor 450/KMK 01/2002 Tentang Perubahan Atas Kep. Menkeu No. 304/KMK 01/2002 Tentang Petunjuk Pelaksanaan Lelang, Tanggal 13 Juni 2002, Pasal. 1 Angka 1

M. Bahsan. (2007). Hukum Jaminan dan Jaminan Kredit Perbankan Indonesia. Ed. 1. Jakarta: PT Raja Grafindo Persada.

Pasal 1 point 4 Peraturan Menteri Keuangan Peraturan Menteri Keuangan Nomor: 93/PMK.06/2010 tertanggal 23 April 2010.

Salim. (2004). Perkembangan Hukum Jaminan di Indonesia. Jakarta: PT. RajaGrafindo persada.

Sudikno Mertokusumo. (1998). Hukum Acara Perdata Indonesia. Yogyakarta : Liberty.

Wahbah az-zuhaili. (2011) Fiqh Islam wa Adillatuhu. Jilid 8. Jakarta: Gema Insani dan Darul Fikr

Yahya Harahap. (2005). Ruang Lingkup Permasalahan Eksekusi Bidang Perdata, Ed.2, Jakarta: Sinar Grafika. 